\title{
Review \\ Causal Effects between Criteria That Establish the End of Service Life of Buildings and Components
}

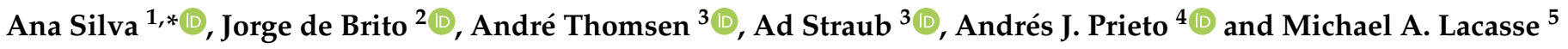 \\ 1 CERIS, Department of Civil Engineering, Architecture and Georesources, IST-University of Lisbon, \\ Av. Rovisco Pais, 1049-001 Lisbon, Portugal \\ 2 Department of Civil Engineering, Architecture and Georesources, IST-University of Lisbon, Av. Rovisco Pais, \\ 1049-001 Lisbon, Portugal; jb@civil.ist.utl.pt \\ 3 Department Management in the Built Environment (MBE), Faculty of Architecture and the Built Environment, \\ Delft University of Technology, Julianalaan 34, 2628 BL Delft, The Netherlands; \\ A.F.Thomsen@tudelft.nl (A.T.); A.Straub@tudelft.nl (A.S.) \\ 4 School of Engineering, Pontificia Universidad Católica de Chile, Avenida Vicuña Mackenna, \\ Santiago 4860, Chile; andres.prieto@ing.puc.cl \\ 5 National Research Council Canada, Construction Research Centre, Ottawa, ON K1A 0R6, Canada; \\ michael.lacasse@nrc-cnrc.gc.ca \\ * Correspondence: ana.ferreira.silva@tecnico.ulisboa.pt
}

Citation: Silva, A.; de Brito, J.; Thomsen, A.; Straub, A.; Prieto, A.J.; Lacasse, M.A. Causal Effects between Criteria That Establish the End of Service Life of Buildings and Components. Buildings 2022, 12, 88 . https://doi.org/10.3390/ buildings 12020088

Academic Editor: David Arditi

Received: 20 December 2021

Accepted: 14 January 2022

Published: 18 January 2022

Publisher's Note: MDPI stays neutral with regard to jurisdictional claims in published maps and institutional affiliations.

Copyright: (C) 2022 by the authors. Licensee MDPI, Basel, Switzerland. This article is an open access article distributed under the terms and conditions of the Creative Commons Attribution (CC BY) license (https:// creativecommons.org/licenses/by/ $4.0 /)$.

\begin{abstract}
In the last decades, considerable work has been done regarding service life prediction of buildings and building components. Academics and members of the CIB W080 commission, as well as of ISO TC 59/SC14, have made several efforts in this area and created a general terminology for the concept of service life, which is extremely relevant for property management, life cycle assessment (LCA) and life cycle costs (LCC) analyses. Various definitions can be found in the literature that share common ideas. In fact, there are different criteria that trigger the end of a building's service life, but the trap that building practitioners too often fall into and that should be avoided is dividing a problem into separate boxes, labels, and specializations without the mutual cohesion and interaction, and ignoring human behavior. Some definitions of service life are discussed in this review paper, in which the cause-effect processes underlying aging and decay are described. These descriptions highlight the continuous interrelation between different criteria for the end of a building's service life, considering too often neglected and misunderstood causes of the end of life.
\end{abstract}

Keywords: service life; buildings' components; property management

\section{Introduction}

Like humans, buildings and their components also are "born", "get older" and "die" [1]. The "birth" of a building is easy to identify, i.e., the beginning of its service life starts as soon as the building is put into use [2]. However, the end of a building's service life is difficult to predict, as this depends on both objective and subjective demands. The "end of service life" can be seen as a normative concept, since without human intervention (e.g., maintenance actions) the building may physically endure until collapse.

How then can the concept of service life be defined? Perhaps the first definition of service life can be found in the Hammurabi Code (c.1950 to 1910 BC) as "a house should not collapse and kill anybody" [3]. In the last decades, several studies and methodologies have been developed regarding service life prediction of buildings and components. These studies have arisen from the need for reliable knowledge about the durability of building elements so that more sustainable strategies can be adopted regarding maintenance activities and the management of a building's life cycle. Service life data have mostly been used in research fields that include property management [4], life cycle analysis (LCA), and life cycle cost analysis (LCC). LCA and LCC results are strongly dependent on assumptions regarding the service life of buildings and their components. These assumptions are often 
limited to standardized values of 30 to 50 years but, in reality, the buildings and their components' lifetime vary considerably, first because each building (as a whole) is a unique prototype and then because some components present shorter service lives. Therefore, the adoption of standard assumptions tends to lead to incorrect results [5]. A critical literature review performed by Silva and de Brito [6] revealed that guidelines and standards propose a standardized average value for all the cladding solutions, usually adopting a too optimistic value in less durable claddings and a too pessimistic in more durable claddings. This study [6] reveals that the estimations provided by sampling seem to be more reliable and adjusted to the actual durability of building components.

The concepts and terminology in service life prediction present some variations, with different meanings and connotations, depending on the scope of the different studies carried out. In this sense, in the literature, different terms can be used with the same meaning, and the same terminology can be used to describe different concepts.

Different standardization documents [7-10] have been developed, which were intended to harmonize the concept of service life. Awano [11] separates the life of a building into two categories: "real life", where the life of a building is conditioned by its physical condition; and "service life", which is conditioned by the capability of a building to fulfill its function and other performance criteria. Brand [12] mentioned that buildings lose their capability to meet minimum performance requirements at two different rates: a slower rate related to the natural aging of materials, referring to the physical deterioration that occurs over time; and a more variable but faster rate, related to changes dictated by aesthetic (e.g., new materials or construction trends) or legal motives (e.g., fire safety or the presence of materials that are not allowed anymore, as asbestos), or due to variations in the social context (e.g., changes in users' demands). Moreover, Brand [12] divided the building into durability layers, i.e., construction subsystems whose degradation occurs at different paces, among which are the "structure", the "skin", the "systems" and the "interior lay-out and finishes" [1]. Therefore, instead of an end of service life, one can speak of different ends of service life of the various parts of the building, according to the performance criteria considered relevant. The average service life results from the average of the values of the remaining service times of each element considering the relative importance of each one. For example, some elements can easily be replaced, e.g., ceramic wall cladding tile, while the degradation of structural elements can jeopardize the building's use, leading to its rehabilitation or demolition.

There are several definitions in the literature that describe the loss of a building's ability to meet minimum performance requirements. Service life estimates should consider the various reasons for establishing the end of service life of a building and its components but there are various interrelating parameters. In this study, an exhaustive literature review is provided, based on the collection of information over several years, and based on the authors' experience on service life prediction, who are active members of the CIB W080 and ISO TC 59/SC14 commission. This review presents different perspectives regarding the concept of service life and obsolescence and the criteria that trigger the need for maintenance, repair, or replacement of a building and its components. Section 2 describes the concepts of service life and obsolescence; Section 3 confronts the concepts of serviceability and functionality; Section 4 considers the cause-effect dimensions of obsolescence; Section 5 discusses the causal effects between criteria to establish the end of service life of a building and its components.

\section{Service Life and Obsolescence}

In the ISO 15686-1 [13] standard, service life is defined as the period after installation during which a building or its components meets or exceeds the performance requirements. Another relevant concept is the "design service life" [9,13], also referred to as "planned service life" [7] or "design life" [8] or "design working life" [10] and defined as the service life that the designer intends an item (product, component, assembly or construction) to achieve when subjected to the expected service conditions and maintained according to a prescribed maintenance 
management plan. Haapio and Viitaniemi [14] refer to service life as the period during which a building or component is able to fulfill the users' objective and subjective needs, without unacceptable maintenance costs or losses to third parties.

A building's safety and functionality are usually seen as objective needs [15-19]. Aesthetic and social reasons, as well as the users' comfort and well-being, are usually seen as subjective demands, varying from user to user, and changing over time [20,21]. In some studies [12,22], it is revealed that the building components are often replaced before the end of their service life, and this is mainly due to subjective reasons, leading to "obsolescence-based" maintenance actions.

The term obsolescence is defined, according to ISO 15686-1 [13], as the loss of the ability of a building element to perform satisfactorily due to changes in performance requirements. In dictionaries, obsolescence is described as the process of becoming old-fashioned or out-of-date [23]. Various authors [24-29] relate to a building's obsolescence to their loss of performance or utility, which can be caused by their physical deterioration or due to economic and social motivations, technological or political changes, or even fluctuations in users' needs. In this sense, an obsolete building element may not be damaged or dysfunctional, but instead, it can no longer fulfill the users' needs considering more recent and up-to-date standards [30].

Therefore, the service life and the obsolescence of building elements can be described as the incapability of fulfilling performance requirements and the user's needs, but these requirements are constantly changing over time. In this sense, the meaning of "utility" is a key concept in this definition [31]. Nevertheless, it is not possible to measure objectively the concept of "utility", which makes it extremely difficult to measure the limit that establishes the end of service life or the instant after which the constructive element becomes obsolete. Usually, a conventional limit is adopted to establish the end of service life of a building element, considering various acceptance criteria.

\section{Serviceability and Functionality}

The first contribution in the scope of the analysis of a building's functionality appeared at the beginning of the 70s; Markus et al. [32] highlighted the relevance of understanding the humans' role in the definition of the criteria to evaluate a building's performance. In the 80s, CIB [33] introduced the adoption of test methods to quantify physical properties (e.g., thermal conditions, through the assessment of the heating/cooling demands) to ascertain a building's performance. Rush [34] put forward the idea of analyzing a building's performance as a whole, considering building physics, social and psychological aspects, as well as economic factors. The concept of serviceability in construction was initially introduced by Master and Brandt [35], referring to serviceability as the capability of a building or component to perform the function for which it has been specifically designed and used. Andersen and Brandt [36] related the concept of service life with those of serviceability and functionality, referring that a building's service life can be described as the period of time during which at least the basic performance properties are maintained at an acceptable level. Davis and Szigeti [37] described serviceability as the ability of the building to support the activities performed by the users and owners, being able to perform the functions for which they were designed.

The users' demands are considered to be increasingly dynamic [38]. In this sense, buildings and components must be able to constantly adapt in order to fulfill the users' demands and to comply with the performance-based building legislation, which itself is constantly changing $[39,40]$.

In recent decades, various methodologies have been put forward to appraise buildings' functionality. Lützkendorf et al. [41] evaluated a building's functional performance, considering a building's use, its accessibility, and capability to adapt to the users' changing needs. Preiser and Vischer [42] indicated that building performance in a post-occupancy stage can be defined as the boundary between criteria and design $[43,44]$. The study of Blok and Teuffel [45] also relates the term functionality with flexibility, describing it as the 
capability of the building to adapt to new needs. This study highlights that the "functional service life" of a building is more a question of a stakeholder's decision rather than a physical or technical service life. Various authors [46-49] have created a new digital tool to estimate the functional performance and service life of heritage buildings, taking into account external risks (e.g., static-structural, atmospheric, and anthropic conditions) and variables related to building vulnerability (e.g., geological location, constructive system, roof design, conservation state, amongst other variables). Augenbroe [50] proposed an innovative virtual experiment to measure how well a technical solution fulfills the users' requirements, focusing on the impact of building performance simulation in a building's design. More recently, climate change has emerged as a new challenge to attaining the expected life of a building. Hence, the impact of climate change on the functionality of a building and its elements has been discussed [51,52], where the need to change a building's components, elements, or systems must be evaluated so that a building can accommodate new requirements to adapt to the changing environmental conditions.

The two terms are interrelated, but they refer to different concepts, as discussed in more detail in Section 5.2.

\section{Cause-Effect Dimensions of Obsolescence}

The concept of obsolescence is difficult to define. Buildings become obsolete due to a variety of reasons, which are typically interdependent and correlated with each other [53]. Common causes can easily be found between different types of obsolescence.

Once considered 'obsolete', a building is typically subjected to maintenance, rehabilitation, or replacement/demolition. The reasons why the building is subjected to maintenance are commonly categorized as being either predictable or unpredictable. Marteinsson [54] has denoted that, whilst the physical degradation is a measurable parameter, social and legal reasons are more challenging or even impossible to predict.

Iselin and Lemer [55] suggested that building obsolescence tends to occur due to endogenous (e.g., inadequate use of materials) and exogenous causes (e.g., climate degradation agents). In another approach, Nutt et al. [56] suggested that the obsolescence of buildings can occur due to either physical deterioration or behavioral factors (e.g., users' needs).

Various authors $[57,58]$ differentiate "physical deterioration" from "physical obsolescence", suggesting that whereas "physical deterioration" occurs due to expected phenomena (e.g., wear and tear), "physical obsolescence" occurs due to sudden events, linked to the users' behavior. Other authors $[55,59,60]$ applied the two terms arbitrarily, considering that the physical deterioration of a building is an underlying form of physical obsolescence [26].

In a more recent approach, Thomsen and Van der Flier [28,29] suggested that the conceptualization of obsolescence could be described by the quadrant-matrix presented in Figure 1. This correlation matrix considers four parameters, thereby establishing a conceptual model to describe a building's obsolescence and considers the correlation between them. Quadrant A represents the "building obsolescence" as initially described by Baum [61]. This type of depreciation occurs due to internal or endogenous characteristics of buildings, namely inadequate design, lack of maintenance, and the natural wear and aging process that leads to a building's physical deterioration. Quadrant B represents the "physical location obsolescence", in which a building's obsolescence occurs due to exogenous factors related to changes in local conditions, e.g., changes in the environment by adjacent buildings or by traffic, changes in local laws, emerging standards, and rising functional demands. Quadrant C represents behavioral conditions related to the proprietor's or users' attitudes, as misuse or changes in the required functions. Quadrant D is related to behavioral effects due to changes in local conditions, e.g., increase of the criminality and social depreciation of the neighborhood, loss of market status and value, availability of better options. 


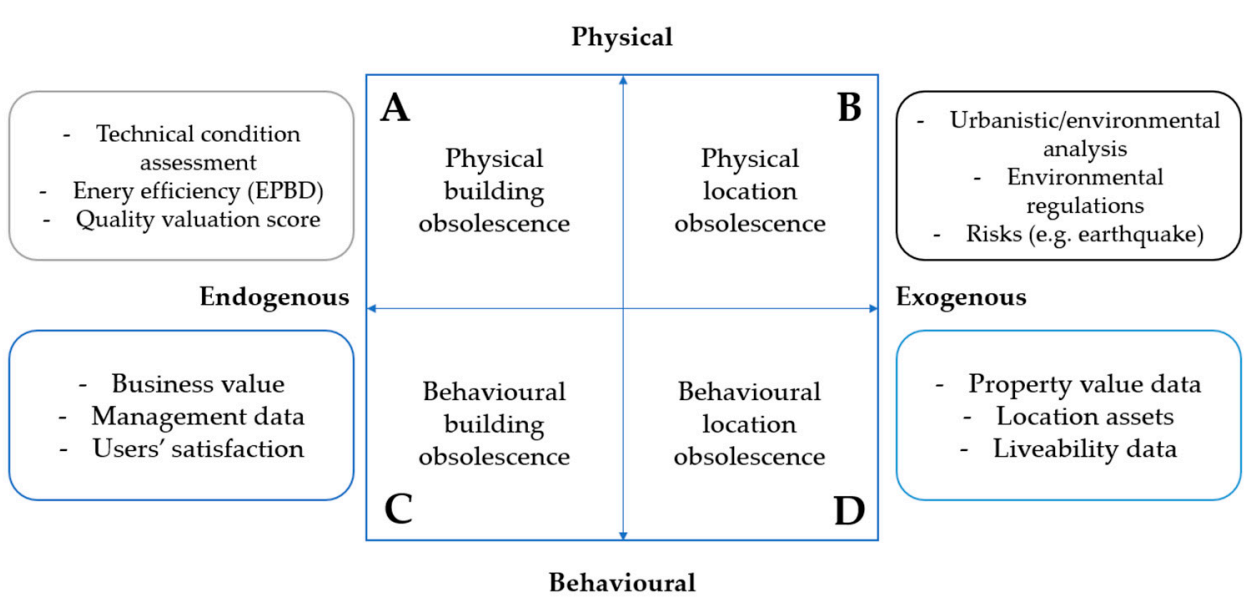

Figure 1. Extended diagram of the two main cause-effect dimensions of obsolescence (adapted from Thomsen and Van der Flier [28,29]). Copyright 2022 Copyright Informa UK Limited; Copyright 2011 Copyright Thomsen, A. and Van der Flier, K.

The analytical model proposed in Figure 1 is based on the premise that obsolescence occurs due to a sequence of complex, frequent, and interconnected cause-effect processes at different scales within and between the four quadrants of the model, leading to the depreciation of the building.

These seem to be the principal cause-effect dimensions of obsolescence since even if the physical service life can be prolonged indefinitely, the end of service life of a given element will occur anyway, since it is rooted in the users' behavior and can be caused by aesthetic, legal, technological or functional, economic, or social reasons [61-63].

\section{Discussion of the Criteria That Trigger the End of a Building's Service Life}

Analyzing the criteria that trigger the end of a building's service life in separate layers seems an impossible task, since the end of a building's service life occurs, most of the time, due to a set of factors that are interrelated to each other. Notwithstanding the evident challenges, various authors, and as is found in different standards documents [1,2,7,8,13,64-67], in a simplified way, have split the concept of service life into different types of service life. In the following sections, the criteria that trigger the end of a building's service life are discussed, in accordance with various types of service life or obsolescence as referenced in the literature.

\subsection{End of Service Life Triggered by Physical Degradation}

Contrarily to the building owner's common beliefs, the physical deterioration is not the dominant factor for the end of a building's service life [68,69]. In real world situations, the end of service life due to physical deterioration can have distinct connotations, according to the type of building or component analyzed [12,70].

For structural elements, due to safety requirements, the end of service life is usually conditioned by economic or functional criteria, rarely reaching the end of their physical service life [71].

Concerning the building envelope, the end of service life depends on the type of use of the building. According to Itard and Meijer [72], fundamental differences can be observed in commercial compared to residential, rented compared to owned, and single compared to joint ownership buildings. The performance of maintenance activities is also highly dependent on the tenure profile. Usually, a planned preventive maintenance strategy tends to be adopted in the rented sector (which has revenue intents). On the other hand, in the residential owner-occupied sector, maintenance activities are essentially reactive, in response to existing anomalies due to physical deterioration. Therefore, the end of a building's physical service life is usually attained or exceeded $[28,29]$. On the other hand, a regular maintenance plan is usually adopted for buildings with revenue intents; thus, 
the façades are subjected to major interventions even before they have reached the end of their physical service life (considering a conventional limit state according to the owner's requirements).

The end of service life of infrastructure networks is rarely triggered by their physical deterioration since installations are regularly subjected to regular maintenance actions [55]. Therefore, the replacement of equipment and installations is usually conditioned by technical or legal reasons. In this case, "obsolescence" cannot be recognized as the inability of infrastructural networks to meet performance requirements, but rather, as the incompatibility between the performance of the infrastructural network, and the increasing requirements of the users over time [73].

For interior finishes, the end of service life is usually conditioned by fashion or aesthetic criteria, rooted in changes in users' focus on and interest in aesthetics.

Various codes and standards provide an average standardized value for the design life of a building or component (which can vary between 50 to 120 years) $[10,12,13]$. However, it has been shown through various studies that, when considered as a whole, buildings seldom reach their maximum value, conventionally assumed for the end of a building's service life. According to Thomsen and van der Flier [74], defining the instant after which a building fails to comply with the essential performance requirements is a very challenging task. In practice, the end of a building's physical service life can be limitless, when regular and adequate maintenance policies are in place, and a building can, in contrast, be demolished long before reaching its physical or functional limit due to social or legal motives [75].

In real world scenarios, the relevance of physical deterioration to trigger the end of a building's service life is linked to the type of use, construction methods, ownership (and tenure), and culture. lizuka [76] shows that, in 74\% of the circumstances, physical deterioration is responsible for the demolition of bridges, whereas this reason only motivates $26 \%$ of the refurbishment of the current building stock [22]. Horst et al. [77] suggested that, in the USA, the service life of housing ranges from 11 to 32 years, whereas schools only undergo general renovations after 42 years, with a tendency to be discarded after 60 years, mainly due to functional motivations. In this study, it was revealed that the end of service life of tertiary office buildings in Japan tended to be limited by economic reasons, with expected service lives ranging between 23 and 41 years. Wuyts et al. [78] refer that several Japanese houses are used for less than a generation prior to being demolished or abandoned and that the average service life of residential buildings is of only 25 years. Pinder and Wilkinson [23] and Gann and Barlow [79] suggested that the end of service life of an office building is usually triggered by the mutable and growing number of requirements over time. For example, in the United Kingdom, an office building's service life decreased to 40-50 years in the 1950s and 1960s, and to 20-25 years in the 1990s.

\subsection{End of Service Life Triggered by Functional and Technological Demands}

The concept of functional service life [13] is related to three principal parameters that are interrelated (Figure 2); these include:

(i) Functionality, which is usually related to the users' demands, considering the relation between the users' needs and the ability of the building to fulfill these needs or to perform to a given level of demand;

(ii) Serviceability, which is related to the extent to which the building is appropriate or valuable in addressing users' requirements;

(iii) Suitability, which is defined as a building's capability to support the functions or activities required by users [43]. 


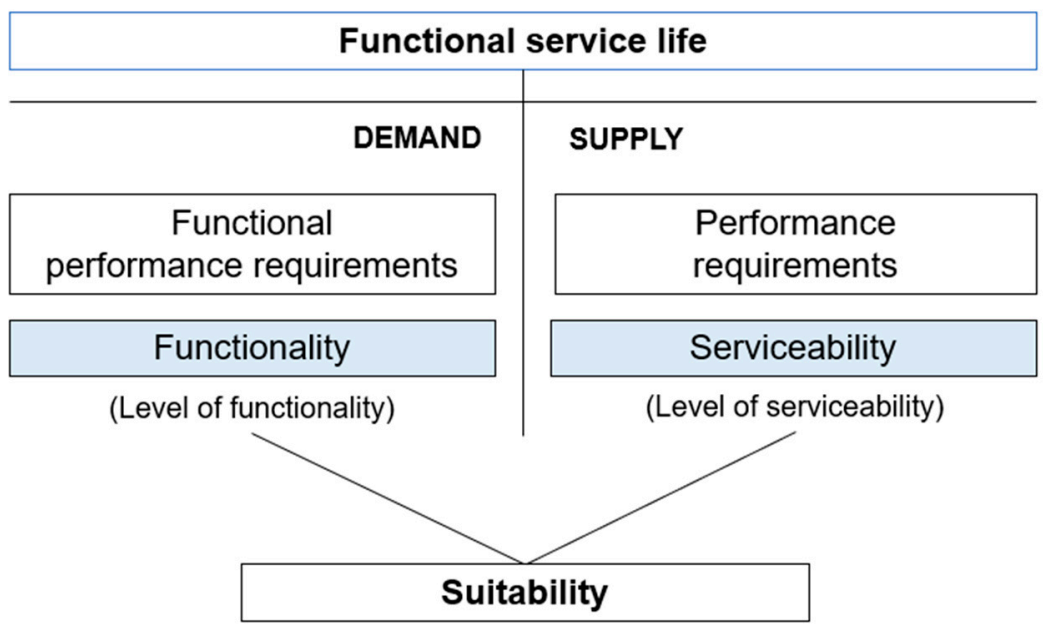

Figure 2. Connection between functionality, serviceability, and suitability.

For example, the same place or room can have different functions (e.g., office work, dining room, or a medical office). When a given place is not suitable for a given use, there is a disparity between the level of functionality required and the level of serviceability offered for that use by the place [13].

Various authors $[80,81]$ have indicated that the end of service life is commonly related to technical criteria, whether conveyed as safety, functional or performance demands. The "functional service life" is described as the period during which the building fulfills adequate functional, or operational performance levels [82]. Under specific conditions, a building's functional performance can be linked to its physical properties [83] (e.g., when the building's physical deterioration compromises its normal use). According to Landman [84], a building's functional service life is intrinsically related to its flexibility and adaptability.

Blok and Teuffel [45] proposed a framework to estimate the end of service life, suggesting values ranging between 30 and 80 years. This huge variation is due to the variability of demands of new stakeholders and advances in the building technology, which tend to trigger the end of a building's functional service life [50,85-87]. For example, for health care facilities, technological criteria seem to be the crucial reason to establish the end of a building's service life, related to upgrading towards modern medical and health care technology; this can lead to a reduction of about $50 \%$ of a building's design service life [88,89]. In reality, the functional service life is based on a demand and supply chain, which is shared between functionality and serviceability, i.e., between the users' needs and a building's functions.

\subsection{End of Service Life Triggered by Legal Requirements}

A building's service life is often conditioned by legal, political, regulatory, or statutory requirements [90-93]. Buildings are designed to comply with current standards; thus, the end of their legal service life is usually triggered as new building legislation is proposed [53,94]. Some authors $[56,95]$ refer to legal obsolescence as control obsolescence, since the end of service life or the need for rehabilitation is triggered by modifications to the legal instruments that control the design and maintenance of buildings.

Wilkinson et al. [96] suggested another term to designate the legal obsolescence, which is political obsolescence, this occurring when trigged by alterations in public or community benefits. Pourebrahimi et al. [26] highlight that the concept of political obsolescence overlaps that of social obsolescence, but the first is ruled by measurable regulatory principles, whereas the second is rooted in social behavior and subjective expectations. According to Williams [97], legal obsolescence can be defined as statutory obsolescence, but the meaning is similar, considering that the building reaches the end of its statutory or legal service life when it is unable to satisfy statutory obligations. 
The performance requirements referred to in the definitions provided in ISO 15,686 [13] are usually related to national building codes or stakeholders' expectations. These legal regulations are frequently related to safety concerns, and economic and cultural circumstances [98]. Once again, it appears that the end of a building's service life is established by criteria that are not mutually exclusive, i.e., there are several motivations that are interconnected, and the end of service life is difficult to split into distinct or isolated concepts.

New policies and guidelines, as well as new urban development plans, can trigger the end of a building's service life (e.g., new thermal comfort codes, fire safety codes, environmental hazards, among others) [99-101].

Various reasons can promote the extension of a building's service life, requiring substantial maintenance costs [102]. In some instances, the service life is prolonged due to political or compulsory regulatory alterations, e.g., when a heritage classification is awarded to a building [103]. In other circumstances, demolishing and reconstructing might impose new and stricter regulations, thereby causing the stakeholders to maintain the building in unsuitable conditions for prolonged periods of time $[100,101]$.

\subsection{End of Service Life Triggered by Social or Community Motivations}

Various authors $[104,105]$ have defined social obsolescence as the decline in suitability or serviceability of a building due to social changes centered on individual or collective perceptions. A building can be in perfect condition but still be abandoned, often long before it reaches undesirable levels of degradation, simply because more advanced, and apparently superior solutions are available $[23,106]$.

A building faces a declining capacity to fulfill the shifting and rising expectations of users over time, as social and political alterations occur [107,108]. These rising expectations are rooted in behavioral aspects, as the users' personal experiences and desires.

Social obsolescence is linked to the social variability of a building's cultural framework, varying at global, regional, and local scales. In this sense, social obsolescence is referred to, in some instances, as cultural obsolescence [109], since this depends on local customs, cultural principles, the users' standard of living and working circumstances. In particular, the acceptance criteria or the tolerance for the deterioration of a building varies by country, within the same country, and even within the same neighborhood. For example, Power [110] has suggested that large-scale social housing commonly represents reduced levels of design and construction quality, minimized construction costs, thereby jeopardizing the safety, comfort, and durability of buildings. Nevertheless, the majority of the tenants reveal reduced levels of demand, thus prolonging a building's service life, whilst in neighborhoods having high economic power, the end of service life can be precipitated due to the users' high level of demand.

Williams [97] describes social obsolescence in a more general way, adopting the term community obsolescence, referring to a building's inability to meet the users' needs due to local conflicts of interest arising from the use of a building. The author highlighted that obsolescence is a subjective idea, since "one man's trash is another man's treasure", and an obsolete building according to a given user or for a given use, may still be very useful for a different user or for other uses.

A building's obsolescence due to social, cultural, or community reasons is rooted in social trends that occur due to alterations in [26,111]: individual and collective preferences and social perceptions; users' lifestyle and the social role of housing and the underlying affairs with family, amenities, schools, transport, and jobs; closeness to familiar attractions; neighborhood identity and local culture; among others.

Preiser and Vischer [42] mentioned that the reasons underlying the performance of rehabilitation actions are, in increasing order of importance: aesthetics, social motivations, psychological aspects; functionality; safety; and health. The users recognize the importance of mitigating the evolution of a building's physical deterioration, but still do not adopt specific measures in this direction. Frequently, the users only complain about a building's 
conditions, when severe degradation levels have already been attained, compromising a building's safety [112].

For decades, the stakeholders and users believed that a building can last forever, but several practical studies demonstrated that the real service life can be abruptly ended, long before the design service life [113]. The example of the Quattrograna West District at Avellino (in Italy) shows how social motives can impose the demolition and reconstruction of an entire neighborhood, after an earthquake, disregarding a building's physical deterioration. The district was rebuilt to promote the users' comfort and well-being, and to stimulate social cohesion $[114,115]$. Another example is the Gailanxi region of Chongqing city, where the early demolition of buildings due to urban renewal requirements leads to significantly short buildings' service lives [116].

The demolition of buildings presents several drawbacks. From an environmental point of view, a building's demolition produces wastes, whose disposal, management, and reuse have an environmental and financial impact. A building's demolition also encompasses social problems, due to the need for ensuring the compensation for financial support of the demolition or alternative housing for those dislocated [110].

Frequently, economic, or financial reasons supersede criteria for physical degradation or social motivations [117]. Different stakeholders have different points of view; investors are predominantly concerned with economic targets, disregarding the users' social value or a building's cultural worth. A study performed for housing organizations, and concerning demolition strategies, raised a suspicion that secret motivations can influence the decision to intervene or demolish. In some situations, the owners may want to demolish or rehabilitate their buildings, even if they comply with functional requirements or provide lower levels of physical deterioration, in order to force the disposal of unwelcome tenants and to revitalize and improve the attractiveness of their assets [118].

\subsection{End of Service Life Triggered by Aesthetics or Architectural Trends}

The end of service life due to aesthetics or architectural trends is almost impossible to model, since this is related to a high degree of subjectivity and personal opinion. Different authors $[96,119,120]$ have introduced the concept of aesthetic or visual obsolescence, indicating that a building becomes obsolete from an aesthetic point of view when it is considered outdated or old-fashioned and no longer fulfills the currently prevalent architectural trends [96].

Aesthetic obsolescence can also be connected to alterations in architectural styles [121]. Other authors $[27,57,58,122]$ have indicated that a building becomes aesthetically obsolete due to changes in its aesthetic attributes (image, fashion trends, among others). Pourebrahimi et al. [26] have indicated that these alterations in style or architecture, or in aesthetic ideals, are unavoidable, and an attractive building today will necessarily become an objectionable building, from an aesthetic point of view, sometime in the future. Marteinsson [123] highlighted that the changes in architectural trends tend to promote the adoption of new requirements concerning the aesthetic appearance of the building, new designs, or the choice of new or different construction materials.

More than would be desirable, aesthetic motivations lead to the replacement of building components, necessarily neglecting their physical deterioration or their technical or economic performance. According to Alaimo and Accurso [124], undertaking rehabilitation actions in buildings is often conditioned by their aesthetic appearance, as well as by their social and urban context.

The Gillender Building is a good example in which aesthetic concerns and social criteria led to a sudden end of the building's service life. This building was constructed in 1897 and demolished in 1910, with a view to being replaced by an even taller building. Abramson [125] listed various examples of "speedy obsolescence" in the United States and particularly in New York (e.g., the Plaza Hotel, the Western Union Building, and the Grand Central Terminal). In the 1910s, this kind of obsolescence became endemic to the city center of America's urban agglomerations, given real estate (economic factors), 
architectural and cultural reasons. Nevertheless, other examples can be found worldwide, in which fashion trends or new demands from an aesthetic point of view helped bring about the end of a building's service life. In the U.K., $46 \%$ of buildings on local authority estates are dismantled after 11 to 32 years [126]. In Japan, office buildings frequently have service lives ranging between 23 and 41 years [127].

For non-structural buildings elements, as interior finishing, the end of service life is commonly triggered by variations in the demographics, i.e., the users' requirements change over their life, and it is simply a matter of time before fashion and style decide the fate of a building. In this sense, the same building element may fulfill an elder owner's needs, but fail to comply with the younger generation's expectations (e.g., the use of rugs as a floor covering system).

In hotels, the replacement and renovation of building components usually occur long before the end of their physical and functional service life, being triggered by aesthetic and fashion motivations, which tend to occur every 5 to 7 years [128].

\section{Conclusions}

The preparation of this paper is a result of efforts from members of the CIB W080 working commission for the conceptualization of building service life. In this study, a theoretical discussion is presented regarding the concept of service life and obsolescence, collected from different perspectives and points of view on an entire complex concept that is service life.

A valuable review has been provided for which the causal effects between the different criteria that dictate the end of buildings' service life are discussed. The impact of endogenous and exogenous factors affecting a building's service life is described, also considering the influence of human behavior on the underlying cause-effect processes that contribute to the end of service life of buildings and components.

In the literature, the different criteria that trigger the end of a building's and building components' service life are described as being separate and unique. From this study, it is now apparent that the different criteria are interrelated and that the end of service life is conditioned by a combination of motives, in cause-and-effect chains, related to e.g., building type, function, location, and ownership.

Due to the multitude of different factors, general conclusions about the lifespan and life expectancy of buildings are overall not possible. More is known and possible at the level of specific building types and parts, particularly in the residential sector, such as applications in LCA. Because this knowledge is essential for meeting the goals of the Paris Agreement (e.g., footprint reduction, lifespan extension, circular construction, and waste minimization), continued research should be focused on relevant specific parts of the building stock.

The literature analyzed in this paper revealed that obsolescence appears to occur, in the majority of the situations, before the physical deterioration of buildings and their components. This knowledge suggests that the current focus on the durability or longevity of the buildings should be rethought. In future studies, it may be interesting to evaluate, e.g., through surveys and case studies analysis, the criteria that most often lead to the end of the service life of buildings and components, evaluating different demand levels, as well as use and ownership profiles.

Author Contributions: Conceptualization, A.S. (Ana Silva), J.d.B.; formal analysis, A.S. (Ana Silva), J.d.B., A.T., A.S. (Ad Straub), A.J.P., M.A.L.; writing—original draft preparation, A.S. (Ana Silva), J.d.B., A.T., A.S. (Ad Straub), A.J.P.; writing—review and editing, A.S. (Ana Silva), J.d.B., A.T., A.S. (Ad Straub), A.J.P., M.A.L. All authors have read and agreed to the published version of the manuscript.

Funding: This research was partially funded by FCT (Portuguese Foundation for Science and Technology) through the project BestMaintenance-LowerRisks (PTDC/ECI-CON/29286/2017) and by the Agencia Nacional de Investigación y Desarrollo (ANID) of Chile through the project ANID FONDECYT 11190554. 
Institutional Review Board Statement: Not applicable.

Informed Consent Statement: Not applicable.

Data Availability Statement: The data presented in this study are available on request from the corresponding author.

Acknowledgments: The authors gratefully acknowledge the support of the CIB W080 commission, the CERIS Research Centre (Instituto Superior Técnico-University of Lisbon), the Pontificia Universidad Católica de Chile, TU Delft (The Netherlands) and Canada National Research Council (NRC).

Conflicts of Interest: The authors declare no conflict of interest.

\section{References}

1. Silva, A.; de Brito, J.; Gaspar, P.L. Methodologies for Service Life Prediction of Buildings: With a Focus on Façade Claddings; 1st ed.; Springer: Geneva, Switzerland, 2016.

2. Rudbeck, C. Methods for Designing Building Envelope Components Prepared for Repair and Maintenance; Report R-035; Department of Buildings and Energy, Technical University of Denmark: Kongens Lyngby, Denmark, 1999; ISBN 87-7877-037-8.

3. Harper, R.F. The Code of Hammurabi, King of Babylon, About 2250 BC: Autographed Text, Transliteration, Translation, Glossary, INDEX OF Subjects, Lists of Proper Names, Signs, Numerals, Corrections and Erasures, with Map, Frontispiece and Photograph of Text; University of Chicago Press: Callaghan, VA, USA, 1904.

4. Straub, A. Estimating the service lives of building products in use. J. Civ. Eng. Arch. 2015, 9, 331-340. [CrossRef]

5. Grant, A.; Ries, R.; Kilbert, C. Life cycle assessment and service life prediction; A case study of building envelope materials. Res. Anal. 2014, 18, 187-200.

6. Silva, A.; de Brito, J. Service life of building envelopes: A critical literature review. J. Build. Eng. 2021, 44, 102646. [CrossRef]

7. Architectural Institute of Japan (AIJ). The English Edition of the Principal Guide for Service Life Planning of Buildings; Architectural Institute of Japan: Tokyo, Japan, 1993.

8. BS 7543; Guide to Durability of Buildings and Building Elements, Products and Components; BSI (British Standards Institution): London, UK, 1992.

9. CSA S478-1995; Guideline on Durability in Buildings; CSA (Canadian Standards Association): Mississauga, ON, Canada, 1995; pp. 9-17.

10. Eurocode 0; Basis of Structural Design; British Standards: London, UK, 2002.

11. Awano, H. Towards Sustainable Use of the Building Stock; OECD—Organisation for Economic Cooperation and Development: Paris, France, 2006.

12. Brand, S. How Buildings Learn—What Happens after They're Built; Orion Books: London, UK, 1997.

13. ISO 15686-1 Buildings and Constructed Assets—Service Life Planning_Part 1: General Principles and Framework; International Organization for Standardization: Geneva, Switzerland, 2011.

14. Haapio, A.; Viitaniemi, P. How workmanship should be taken into account in service life planning. In Proceedings of the 11th International Conference on Durability of Building Materials and Components, Istanbul, Turkey, 11-14 May 2008; pp. 1466-1482.

15. Bordass, W.; Cohen, R.; Staneven, M.; Leaman, A. Assessing building performance in use 2: Technical performance of the Probe buildings. Build. Res. Inf. 2001, 29, 103-113. [CrossRef]

16. Bordass, W.; Cohen, R.; Staneven, M. Assessing building performance in use 3: Energy performance. Build. Res. Inf. 2001, 29, 114-128. [CrossRef]

17. Bordass, W.; Leaman, A.; Ruyssevelt, P. Assessing building performance in use 5: Conclusions and implications. Build. Res. Inf. 2001, 29, 144-157. [CrossRef]

18. Humphreys, M. Quantifying occupant comfort: Are combined indices of the indoor environment practicable? Build. Res. Inf. 2005, 33, 317-325. [CrossRef]

19. Nicol, F.; Roaf, S. Post-occupancy evaluation and field studies of thermal comfort. Build. Res. Inf. 2005, 33, 338-346. [CrossRef]

20. Rybczynski, W. The Look of Architecture; Oxford University Press: New York, NY, USA, 2001.

21. Leaman, A.; Bordass, W. Assessing building performance in use 4: The Probe occupant surveys and their implications. Build. Res. Inf. 2001, 29, 129-143. [CrossRef]

22. Aikivuori, A.M. Critical loss of performance-What fails before durability. In Proceedings of the 8th International Conference on Durability of Building Materials and Components, Vancouver, BC, Canada, 30 May 30-3 June 1999; pp. 1369-1376.

23. Pinder, J.; Wilkinson, S.J. Measuring the Gap: A User Based Study of Building Obsolescence in Office Property; RICS Research Foundation: London, UK, 2001.

24. Mansfield, J.R. Much Discussed, Much Misunderstood: A Critical Evaluation of the Term "Obsolescence". In Proceedings of the RICS Cutting Edge Conference, London, UK, 6-8 September 2000.

25. Mansfield, J.R.; Pinder, J.A. 'Economic' and 'functional' obsolescence: Their characteristics and impacts on valuation practice". Prop. Manag. 2008, 26, 191-206. [CrossRef]

26. Pourebrahimi, M.; Eghbali, S.R.; Roders, A.P. Identifying building obsolescence: Towards increasing buildings' service life. Int. J. Build. Pathol. Adapt. 2020, 38, 635-652. [CrossRef] 
27. Grover, R.; Grover, C. Obsolescence-A cause for concern? J. Prop. Invest. Financ. 2015, 33, 299-314. [CrossRef]

28. Thomsen, A.; Van der Flier, K. Understanding obsolescence: A conceptual model for buildings. Build. Res. Inf. $2011,39,352-362$. [CrossRef]

29. Thomsen, A.; Van der Flier, K. Obsolescence, conceptual model and proposal for case studies. In Proceedings of the 23rd Conference of the European Network of Housing Research: ENHR 2011, Toulouse, France, 5-8 July 2011.

30. Lemer, A.C. Infrastructure obsolescence and design service life. J. Infrastruct. Syst. 1996, 2, 153-161. [CrossRef]

31. Smith, M.; Whitelegg, J.; Williams, N. Materials Intensity in the Built Environment; Greening the Built Environment, Earthscan Publications Ltd.: London, UK, 1998.

32. Markus, T.; Whyman, P.; Morgan, J.; Whitton, D.; Maver, T.; Canter, D.; Fleming, J. Building Performance; Applied Science Publishers: London, UK, 1972.

33. CIB. Working Commission W060 CIB Report 64: Working with the Performance Approach to Building; CIB: Rotterdam, The Netherlands, 1982.

34. Rush, R.D. The Building Systems Integration Handbook; Architectural Press, The American Institute of Architects: New York, NY, USA, 1986.

35. Masters, L.W.; Brandt, E. Systematic methodology for service life prediction of building materials and components. Mater. Struct. 1989, 22, 385-392. [CrossRef]

36. Andersen, T.; Brandt, E. The use of performance and durability data in assessment of life time serviceability-Performance and durability data. In Proceedings of the 8th International Conference on Durability of Building Materials and Components, Ottawa, QC, Canada, 30 May-3 June 1999; pp. 1813-1820.

37. Davis, G.; Szigeti, F. Are facilities measuring up? Matching building capabilities to functional needs-Using the serviceability tools and methods. In Proceedings of the 8th International Conference on Durability of Building Materials and Components, Ottawa, QC, Canada, 30 May-3 June 1999; pp. 1856-1866.

38. Blok, R.; Herwijnen, F.V.; Kozlowski, A.; Wolinski, S. Service Life and Life Cycle of Building Structures; COST C-12; Improving Building Structural Quality by New Technologies: Lisbon, Portugal, 2002.

39. Lacasse, M.A.; Vanier, D.J.; Kyle, B.R. Towards integration of service life and asset management tools for building envelope systems. In Proceedings of the 7th Conference on Building Science and Technology: Durability of Buildings Design, Maintenance, Codes and Practice, Toronto, ON, Canada, 20-21 March 1997; pp. 153-167.

40. Foliente, C. Developments in performance-based building codes and standards. For. Product. J. 2000, 50, 12-21.

41. Lützkendorf, T.; Speer, T.; Szigeti, F.; Davis, G.; Le Roux, P.; Kato, A.; Tsunekawa, K. A Comparison of International Classifications for Performance Requirements and Building Performance Categories Used in Evaluation Methods; Performance Based Building, Technical Research Centre of Finland (VTT)/Association of Finnish Civil Engineers (RIL): Helsinki, Finland, 2005; pp. 61-80.

42. Preiser, W.; Vischer, J. (Eds.) Assessing Building Performance; Routledge, Taylor and Francis: London, UK, 2006.

43. Hammond, D.; Dempsey, J.J.; Szigeti, F.; Davis, G. Integrating a performance-based approach into practice: A case study. Build. Res. Inf. 2005, 33, 128-141. [CrossRef]

44. Grussing, M.N.; Uzarski, D.R.; Marrano, L.R. Building infrastructure functional capacity measurement framework. J. Infrastruct. Syst. 2009, 15, 371-377. [CrossRef]

45. Blok, R.; Teuffel, P. Indicators for functional service life of building structures. In Proceedings of the International Conference Civil Engineering for Sustainability and Resilience (CESARE'14), Amman, Jordan, 24-27 April 2014; p. 52.

46. Macías-Bernal, J.M.; Calama-Rodríguez, J.M.; Chávez-de Diego, M.J. Modelo de predicción de la vida útil de la edificación patrimonial a partir de la lógica difusa. Inf. Constr. 2014, 66, e006. [CrossRef]

47. Prieto, A.J.; Silva, A.; de Brito, J.; Alejandre, F.J. Functional and physical service life of natural stone claddings. J. Mater. Civ. Eng. 2016, 28, 04016150. [CrossRef]

48. Ibáñez, A.J.P.; Bernal, J.M.M.; de Diego, M.J.C.; Sánchez, F.J.A. Expert system for predicting buildings service life under ISO 31000 standard; Application in architectural heritage. J. Cultural Herit. 2016, 18, 209-218. [CrossRef]

49. Prieto, A.J.; Silva, A.; de Brito, J.; Macías-Bernal, J.M. Serviceability of facade claddings. Build. Res. Inf. 2018, 46, 179-190. [CrossRef]

50. Augenbroe, G. The Role of Simulation in Performance-Based Building; Building Performance Simulation for Design and Operation; Routledge, Taylor and Francis: London, UK, 2019.

51. Lacasse, M.A.; Gaur, A.; Moore, T.V. Durability and climate change-implications for service life prediction and the maintainability of buildings. Buildings 2020, 10, 53. [CrossRef]

52. Prieto, A.J.; Verichev, K.; Silva, A.; de Brito, J. On the impacts of climate change on the functional deterioration of heritage buildings in South Chile. Build. Environ. 2020, 183, 107138. [CrossRef]

53. Reed, R.; Warren-Myers, G. Is sustainability the 4th form of obsolescence? In Proceedings of the 16th Pacific Rim Real Estate Society, (PRRES) Conference, Wellington, New Zealand, 24-27 January 2010.

54. Marteinsson, B. Homes in Iceland-flexibility and service life fulfilment of functional needs. In Proceedings of the 11th International Conference on Durability of Building Materials and Components, Istanbul, Turkey, 11-14 May 2008; Volume 2010, pp. 1485-1490.

55. Iselin, D.G.; Lemer, A.C. (Eds.) Fourth Dimension in Building: Strategies for Avoiding Obsolescence; National Research Council, The National Academy Press: Washington, DC, USA, 1993. [CrossRef] 
56. Nutt, B.; Walker, B.; Holliday, S.; Sears, D. Obsolescence in Housing: Theory and Applications; Saxon House and Lexington Books: Farnborough, UK, 1976.

57. Flanagan, R.; Norman, G.; Meadows, J.; Robinson, G. Life Cycle Costing Theory and Practice; BSP Professional Books: Oxford, MS, USA, 1989.

58. Ashworth, A. Estimating the life expectancies of building components in life-cycle costing calculations. Struct. Surv. 1996, 14, 4-8. [CrossRef]

59. API (Australian Property Institute). API Definitions. 2021. Available online: https://www.api.org.au/standards/definitions/ (accessed on 23 March 2021).

60. RICS (Royal Institution of Chartered Surveyors). RICS Valuation-Global Standards. $2017 . \quad$ Available online: https: / / www.rics.org/globalassets/rics-website/media/upholding-professional-standards/sector-standards/valuation/redbook-2017-global-edition-rics.pdf (accessed on 23 March 2021).

61. Baum, A. Property Investment Depreciation and Obsolescence; Routledge Publishing: London, UK, 1991.

62. Kyle, B.R. Toward Effective Decision Making for Building Management. In Proceedings of the APWA International Public Works Congress, NRCC/CPWA/IPWEA Seminar Series "Innovations in Urban Infrastructure", Philadelphia, PA, USA, 9-12 September 2001; pp. 51-69.

63. Geissdoerfer, M.; Savaget, P.; Bocken, N.M.; Hultink, E.J. The Circular Economy-A new sustainability paradigm? J. Clean. Product. 2017, 143, 757-768. [CrossRef]

64. Frohnsdorff, G.; Nireki, T. Integration of standards for prediction of service life of building materials and components and for assessment of design life of buildings. In Proceedings of the EUREKA Conference of Building Technologies, Lillehammer, Norway, 16 June 1994.

65. Nireki, T. Service life design. Constr. Build. Mater. 1996, 10, 403-406. [CrossRef]

66. Soronis, G. Standards for design life of buildings: Utilization in the design process. Constr. Build. Mater. 1996, 10, 487-490. [CrossRef]

67. Marteinsson, B. Durability and the factor method of ISO 15686-1. Build. Res. Inf. 2003, 31, 416-426. [CrossRef]

68. Sarja, A. Generic limit state design of structures. In Proceedings of the 10th International Conference on Durability of Building Materials and Components, Lyon, France, 17-20 April 2005; p. TT3-161.

69. Balaras, C.; Droutsa, K.; Dascalaki, E.; Kontoyiannidis, S. Service life of building elements \& installations in European apartment buildings. In Proceedings of the 10th International Conference on Durability of Building Materials and Components, Lyon, France, 17-20 April 2005; pp. 718-725.

70. Duffy, F. The New Office; Conran Octopus: London, UK, 1997.

71. Gosav, I. Field studies concerning the life service life prediction. In Proceedings of the 8th International Conference on Durability of Building Materials and Components, Ottawa, QC, Canada, 30 May-3 June 1999; pp. 1392-1402.

72. Itard, L.; Meijer, F. Towards a Sustainable Northern European Housing Stock: Figures, Facts and Future; Sustainable Urban Areas; IOS Press: Amsterdam, The Netherlands, 2008; Volume 2.

73. Gaspar, P.L. Service Life of Constructions; Development of a Methodology to Estimate the Durability of Construction Elements, Application to Renders in Current Buildings. Ph.D. Thesis, Engineering Sciences at Instituto Superior Técnico, Lisbon, Portugal, 2009. (In Portuguese)

74. Thomsen, A.; van der Flier, K. Replacement or renovation of dwellings: The relevance of a more sustainable approach. Build. Res. Inf. 2009, 37, 649-659. [CrossRef]

75. Kohler, N.; Hassler, U. The building stock as a research object. Build. Res. Inf. 2002, 30, 226-236. [CrossRef]

76. Iizuka, H. A statistical study of life time of bridges. Struct. Eng. Earthq. Eng. Jap. Soc. Civ. Eng. 1988, 5, 51-60. [CrossRef]

77. Horst, S.; O'Connor, J.; Argeles, C. Survey on actual service lives of north American buildings. In Proceedings of the 10th International Conference on Durability of Building Materials and Components, Lyon, France, 17-20 April 2005; pp. 851-858.

78. Wuyts, W.; Miatto, A.; Sedlitzky, R.; Tanikawa, H. Extending or ending the life of residential buildings in Japan: A social circular economy approach to the problem of short-lived constructions. J. Clean. Product. 2019, 231, 660-670. [CrossRef]

79. Gann, D.M.; Barlow, J. Flexibility in building use: The technical feasibility of converting redundant offices into flats. Construct. Manage. Econ. 1996, 14, 55-66. [CrossRef]

80. Bakens, W.; Foliente, G.; Jasuja, M. Engaging stakeholders in performance-based building: Lessons from the Performance-Based Building (PeBBu) Network. Build. Res. Inf. 2005, 33, 149-158. [CrossRef]

81. Butt, T.E.; Giddings, B.D.; Cooper, J.C.; Umeadi, B.B.N.; Jones, K.G. "Advent of Climate Change and Resultant Energy Related Obsolescence in the Built Environment", Sustainability in Energy and Buildings, Results of the Second International Conference on Sustainability in Energy and Buildings (SEB'10), Smart Innovation, Systems and Technologies; Springer: Berlin/Heidelberg, Germany, 2011; Volume 3, pp. 211-224.

82. Fitch, M.G.; Weyers, R.E.; Johnson, S.D. Determination of end of functional service life for concrete bridge decks. Transp. Res. Rec. 1995, 1490, 60-66.

83. Ford, K.M.; Arman, M.; Labi, S.; Sinha, K.C.; Shirole, A.; Thompson, P.; Li, Z. Methodology for Estimating Life Expectancies of Highway Assets; National Cooperative Highway Research Program: Washington, DC, USA, 2011.

84. Landman, M. Technical Building Properties with the Probability of Elongating the Functional Service Life; Eindhoven University of Technology: Eindhoven, The Netherlands, 2016. 
85. Slaughter, E.S. Design strategies to increase building flexibility. Build. Res. Inf. 2001, 29, 208-217. [CrossRef]

86. Meacham, B.; Bowen, R.; Traw, J.; Moore, A. Performance-based building regulation: Current situation and future needs. Build. Res. Inf. 2005, 33, 91-106. [CrossRef]

87. Trinius, W.; Sjöström, C. Service life planning and performance requirements. Build. Res. Inf. 2005, 33, 173-181. [CrossRef]

88. Mc Duling, J.; Horak, E.; Cloete, C. Service life prediction beyond the factor method. In Proceedings of the 11th International Conference on Durability of Building Materials and Components, Istanbul, Turkey, 11-14 May 2008; pp. $1515-1522$.

89. Mc Duling, J.; Abbott, G. Service life and sustainable design methods: A case study. In Proceedings of the 11th International Conference on Durability of Building Materials and Components, Istanbul, Turkey, 11-14 May 2008; pp. 1663-1669.

90. Conejos, S.; Langston, C.; Smith, J. Designing for better building adaptability: A comparison of adaptSTAR and ARP models. Habitat Int. 2014, 41, 85-91. [CrossRef]

91. Langston, C. Estimating the useful life of buildings. In Proceedings of the 36th Australasian University Building Educators Association (AUBEA) Conference, Gold Coast, Australia, 27-29 April 2011.

92. Langston, C. Validation of the adaptive reuse potential (ARP) model using iconCUR. Facilities 2012, 30, 105-123. [CrossRef]

93. Chaplin, R.I. The threat of obsolescence to police precincts on the heritage 'beat'. Int. J. Herit. Stud. 2003, 9, 117-133. [CrossRef]

94. Tan, Y.; Shen, L.Y.; Langston, C. A fuzzy approach for adaptive reuse selection of industrial building in Hong Kong. Int. J. Strateg. Prop. Manag. 2014, 18, 66-76. [CrossRef]

95. Raftery, J. Principles of Building Economics; BSP Professional: Oxford, UK, 1991.

96. Wilkinson, S.J.; Remøy, H.; Langston, C. Sustainable Building Adaptation: Innovations in Decision-Making; John Wiley \& Sons: West Sussex, UK, 2014.

97. Williams, A. Remedying industrial building obsolescence: The options. Prop. Manage. 1986, 4, 5-14. [CrossRef]

98. Hed, G. Service Life Planning in Building Design. In Proceedings of the 14th CIB World Building Congress, Gavle, Sweden, 22-24 February 1998; pp. 201-209.

99. Fu, F.; Pan, L.; Ma, L.; Li, Z. A simplified method to estimate the energy-saving potentials of frequent construction and demolition process in China. Energy 2013, 49, 316-322. [CrossRef]

100. Dias, W.P.S. Useful Life of Buildings; University of Moratuwa: Moratuwa, Sri Lanka, 2003.

101. Dias, W.P.S. Factors influencing the service life of buildings. J. Inst. Eng. 2013, 46, 1-7. [CrossRef]

102. Rauf, A.; Crawford, R.H. Building service life and its effect on the life cycle embodied energy of buildings. Energy 2015, 79, 140-148. [CrossRef]

103. Kincaid, D. Adaptability potentials for buildings and infrastructure in sustainable cities. Facilities 2000, 18, 155-161. [CrossRef]

104. Forster-Kraus, S.; Reed, R.; Wilkinson, S. Affordable housing in the context of social sustainability. In Proceedings of the ISA International Housing Conference, Glasgow, UK, 21-26 April 2009.

105. Rodi, W.N.W.; Hwa, T.K.; Said, A.S.; Mahamood, N.M.; Abdullah, M.I.; Abd Rasam, A.R. Obsolescence of green office building: A literature review. Proc. Econ. Financ. 2015, 31, 651-660. [CrossRef]

106. BRB-Building Research Board. The Fourth Dimension in Building: Strategies for Minimising Obsolescence; National Academy Press: Washington, DC, USA, 1993.

107. Ohemeng, F.A.; Mole, T. Value-focused approach to built asset renewal and replacement decisions. In Proceedings of the CuttingEdge Conference, Birmingham, UK, 20-21 September 1996; RICS—Royal Institution of Chartered Surveyors: Birmingham, UK, 1996.

108. Bryson, J.R. Obsolescence and the process of creative reconstruction. Urb. Stud. 1997, 34, 1439-1458. [CrossRef]

109. Sarja, A. Predictive and Optimised Life Cycle Management; Taylor and Francis: London, UK, 2006.

110. Power, A. Does demolition or refurbishment of old and inefficient homes help to increase our environmental, social and economic viability? Energy Policy 2008, 36, 4487-4501. [CrossRef]

111. Sarja, A. Reliability principles, methodology and methods for lifetime design. Mater. Struct. 2010, 43, 261-271. [CrossRef]

112. Flores-Colen, I.; de Brito, J.; Freitas, V. Discussion of criteria for prioritization of predictive maintenance of building façades-survey of 30 experts. J. Perform. Constr. Facil. 2010, 24, 337-344. [CrossRef]

113. O'Connor, J. Survey on actual service lives for North American buildings. In Proceedings of the Woodframe Housing Durability and Disaster Issues Conference, Las Vegas, NV, USA, 4-6 October 2004.

114. Marino, F.P.R. The pathologies of the industrialized systems: 1.023 flats realized in Avellino (Italy) in the ' $80 \mathrm{~s}$. In Proceedings of the Construction in the XXI Century: Local and Global Challenges, joint 2006 CIB W065/W055/W086 International Symposium, Rome, Italy, 18-20 October 2006.

115. Marino, F.P.R. Pathologies of the industrialized systems: 192 flats built in Avellino (Italy) at Quattrograna west district. In Proceedings of the 11th International Conference on Durability of Building Materials and Components, Istanbul, Turkey, 11-14 May 2008; p. T71.

116. Shen, L.Y.; Yuan, H.; Kong, X. Paradoxical phenomenon in urban renewal practices: Promotion of sustainable construction versus buildings' short lifespan. Int. J. Strateg. Prop. Manag. 2013, 17, 377-389. [CrossRef]

117. Farahani, A.; Wallbaum, H.; Dalenbäck, J.-O. The importance of life-cycle based planning in maintenance and energy renovation of multifamily buildings. Sust. Cit. Soc. 2019, 44, 715-725. [CrossRef]

118. Van der Flier, K.; Thomsen, A. The Life Cycle of Dwellings and Demolition by Dutch Housing Associations; Gruis, V., Visscher, H., Kleinhans, R., Eds.; Sustainable Neighbourhood Transformation; IOS Press/DUP: Amsterdam, The Netherlands, 2006. 
119. Remøy, H. Out of Office: A Study on the Cause of Office Vacancy and Transformation as a Means to Cope and Prevent. Ph.D. Thesis, Delft University of Technology, Delft, The Netherlands, 2010.

120. Dunse, N.; Jones, C. Rental depreciation, obsolescence and location: The case of industrial properties. J. Prop. Res. 2005, 22, 205-223. [CrossRef]

121. Douglas, J. Building Adaptation, 2nd ed.; Spon Press: Abington, MA, USA, 2006.

122. Johnston, K. Obsolescence and Renewal: Transformation of Post War Concrete Buildings. Master's Thesis, Architecture, University of Maryland, College Park, MD, USA, 2016.

123. Marteinsson, B. Service Life Estimation in the Design of Buildings; A Development of the Factor Method. Ph.D. Thesis, KTH Research School Department of Technology and Built, Centre for Built Environment, University of Gävle, Gävle, Sweden, 2005.

124. Alaimo, G.; Accurso, F. The assessment of durability of discontinuous roofing: An experiment on sandwich panels. In Proceedings of the 11th International Conference on Durability of Building Materials and Components, Istanbul, Turkey, 11-14 May 2008; p. T22.

125. Abramson, D.M. Obsolescence: An Architectural History; The University of Chicago Press: Chicago, IL, USA, 2016.

126. Pieda, D.T.Z. Consulting Demolition and New Building on Local Authority Estates; U.K. Department of the Environment, Transport and the Regions: London, UK, 2000.

127. Yashiro, T.; Kato, H.; Yoshida, T.; Komatsu, Y. Survey on real life span of office buildings in Japan. In Proceedings of the CIB 90 W55/65 Symposium, Sydney, Australia, 14-22 March 1990; pp. 215-226

128. International Society of Hospitality Consultants (Ed.) CapEx2014: A Study of Capital Expenditures in the Hotel Industry; American Hotel \& Lodging Educational Institute: Lansing, MI, USA, 2015. 